\title{
Assessing Indonesia-Russia Foreign Policy during Susilo Bambang Yudhoyono Administration
}

\author{
Marten Hanura \\ Department of International Relations, Faculty of Social \& Political Sciences, \\ Universitas Diponegoro \\ E-mail: marten.h@live.undip.ac.id
}

\begin{abstract}
Russia or formerly known as the Soviet Union has a historically unique cooperation and diplomatic relations with Indonesia. This is because the relationship between Indonesia and Russia has a long history and experiencing ups and downs. The closeness of the two countries was influenced ideologically in the early days of Indonesian independence, and later the rise of the New Order regime influenced the dynamics of Indonesian foreign policy. During the New Order period, the Indonesian government began to freeze all forms of cooperative relations with the Soviet Union. The collapse of the Soviet Union and the end of the Cold War era began to change the map of international politics to affect the situation in Indonesia. In the Post-Reformation era, the normalization of relations between the two countries recovered and lasted until the administration of President Susilo Bambang Yudhoyono. The purpose of this article is to find out how the changes in the implementation of the foreign policy of Indonesia-Russia during the administration of President Susilo Bambang Yudhoyono with the previous era and what factors underlie Indonesia's foreign policy towards Russia. This research uses the descriptive-analytical method and using some theoretical concepts in the foreign policy-making process. The results of this study concluded that foreign policy between Indonesia and Russia increased significantly in the Post-Reformation era which no longer saw Russia as a threat as in the New Order era. The cooperation between Indonesia and Russia is implemented in various main areas, prominently is the cooperation in the field of military, social, economic and political.
\end{abstract}

Keywords: Foreign Policy; Indonesia-Russia; Susilo Bambang Yudhoyono; Bilateral Relations

\begin{abstract}
Abstrak
Rusia atau yang sebelumnya lebih dikenal dengan nama Uni Soviet secara historis memiliki hubungan kerjasama dan diplomatik dengan Indonesia cukup unik. Hal ini disebabkan hubungan antara Indonesia dan Rusia memiliki sejarah panjang dan mengalami pasang surut. Kedekatan kedua negara dipengaruhi secara ideologis pada masa awal Kemerdekaan Indonesia, kemudian naiknya rezim Orde Baru mempengaruhi dinamika kebijakan luar negeri Indonesia. Pada masa Orde Baru, pemerintah Indonesia mulai membekukan semua bentuk hubungan kerjasama dengan Uni Soviet. Ambruknya Uni Soviet dan berakhirnya era perang dingin mulai merubah peta politik internasional hingga berpengaruh pada situasi di Indonesia. Pasca-Reformasi, normalisasi hubungan antara kedua negara kembali pulih dan berlangsung hingga pada masa Presiden Susilo Bambang Yudhoyono. Tujuan artikel ini ditulis untuk mengetahui bagaimana perubahan implementasi kebijakan politik luar negeri Indonesia-Rusia selama pemerintahan Presiden Susilo Bambang Yudhoyono dengan era sebelumnya dan faktor-faktor apa saja yang mendasari kebijakan luar negeri Indonesia kepada Rusia. Penelitian ini menggunakan metode desktriptif analitis dan menggunakan beberapa konsep teori dalam proses pembuatan kebijakan luar negeri. Hasil dari penelitian ini diperoleh kesimpulan bahwa kebijakan politik luar negeri antara Indonesia dengan Rusia meningkat secara signifikan pasca era-Reformasi dimana tidak lagi melihat Rusia sebagai ancaman seperti pada era-Orde Baru. Kerjasama antara Indonesia dengan Rusia terimplementasikan dalam berbagai bidang utamanya yang menonjol adalah kerjasama dalam bidang militer, sosial, ekonomi dan politik.
\end{abstract}

Kata kunci: Kebijakan Luar Negeri; Indonesia-Rusia; Susilo Bambang Yudhoyon; Hubungan Bilateral 


\section{INTRODUCTION}

Russia, or formerly known as the Soviet Union has a historically unique cooperation and diplomatic relations with Indonesia. This is due to the ideological closeness in the early days of independence. The era in which there is still much practice of colonialism and Western domination in developing countries that made Indonesia prefer close to a country that opposes colonialism like the Soviet Union and China.

The international order at that time made changes to the prevailing international system. At the time of the Cold War, the researchers could mutually agree in determining the international system that prevailed at that time, the bipolar international system with its two main actors, the United States and the Soviet Union. Under the current international system, world leaders can formulate their policies on that basis. The choice to be taken by foreign policymakers is also relatively "easy", that is, to base their foreign policy orientation on one of the world's great powers, whether it is oriented towards Washington and Capitalism, or to Moscow and Communism (Hidayat, 2017: 233). This is what makes the closeness of the relationship between Indonesia and the Soviet Union at the beginning of Indonesian independence history because of the ideas echoed by the Soviet Union to oppose colonialism and imperialism is in accordance with the interests of Indonesia who want to escape from the grip of the colonialists.

The rise of the New Order regime influenced the dynamics of Indonesian foreign policy, especially in treating Indonesia's foreign relations with communist countries like the Soviet Union. The Indonesian government froze any form of cooperative relationship with the Soviet Union after 1965. However, the collapse of the Soviet Union and the end of the Cold War era in 1991 affected changes in international political maps, including the influence of the IndonesianRussian relationship to the present day.

This research is very interesting to know how the foreign policy between Indonesia and Russia in the form of cooperation in various fields during the time of SBY and what is the basis behind the policy of Indonesia's foreign policy towards Russia. This article is written to fill the gap for research related to Indonesia's foreign policy relations with Russia which is still rare, especially if linked to the foreign political relations between Indonesia and Russia during Susilo Bambang Yudhoyono administration.

Research on foreign policy between Indonesia and Russia is still very minimal, including research of Dr. Aelina Surya (2009) from Universitas Padjajaran under the title "Antara Indonesia dan Rusia: Sebuah Tinjauan Sejarah" (Between Indonesia and Russia: A Historical Review). This study is more about the historical relationship between Indonesia and Russia with no basis on the point of view of foreign policy factors. Another study, Setyasih 


\section{Jurnal Ilmu Sosial Vol. 17 | No. 1 | Edisi Januari - Juni 2018 | Hall1-20}

Harini (2012), entitled "Kebijakan Presiden Vladimir Putin Dalam Menjalin Kerjasama dengan Indonesia” (President Vladimir Putin's Policy in Partnership with Indonesia), further discussed the cooperation between Indonesia and Russia from the point of view of Vladimir Putin (Russia) where the contents are not much discussed from the point of view of SBY's foreign policy (Indonesia). It can be said that there is still a lack of previous research about Russia's foreign policy from Indonesian point of view especially during SBY administration, let alone related to from what basis that SBY held cooperation with Russia which seen from the point of view of the Indonesia's foreign policy. We know that SBY himself is a figure of the President who is close to the United States, in fact, SBY once said that America is the second home for SBY. Thus, the results of this study is to determine whether the existence of cooperation between Indonesia and Russia put a distance between Indonesia and United States relationship or whether there are limitations in the relationship of cooperation between Indonesia and Russia.

\section{RESEARCH METHODS}

This research uses a descriptive-analytical method to describe the implementation of foreign policy between Indonesia and Russia. The data type used is secondary data obtained from the Ministry of Foreign Affairs of the Republic of Indonesia of the Directorate of America and Europe, the Embassy of the Republic of Indonesia in Russia, the Russian Embassy in Indonesia, and data from various Universities and other Research Institutions which also examine Indonesia-Russia foreign policy.

To obtain accurate results and in accordance with the needs of research, the research activities are conducted at two stages of activity. First, to examine in terms of Indonesia's foreign policy relations with Russia with a focus on the origins, developments, theoretical foundations, best practices \& bad practices, and constraints in the implementation of the foreign relations of both countries. While the second phase focuses on extracting primary data related to the implementation of Indonesia-Russia foreign relations by searching the data directly from the stakeholders.

Second, searching the primary data into the field to obtain a valid and accurate picture of the condition of the two countries that have the potential to establish foreign political relations. Potentials are determined, among others, with the conditions and needs of both countries. In addition, the primary data is also extracted through interview mechanisms either directly or indirectly. 


\section{RESULTS AND DISCUSSION}

Foreign political relations and cooperation between Indonesia and Russia have been established for a long time. The situations and conditions, both international and domestic systems also affect the relationship between the two countries. Each regime changes, the intensity of relations between the two countries is different. From Soekarno, Soeharto, BJ Habibie, Gus Dur, Megawati to Susilo Bambang Yudhoyono has different international and domestic situation. This situation then led to the response of different foreign policy policies of each regime.

When the Reformation occurs, the situation is uncertain. Domestic situation has not been stable until after the administration of Megawati, that is during the SBY administration. SBY is a president in the Post-Reformation era that has two major assets, namely political and security stability, as well as having high legitimacy. This is in contrast to Megawati's government which is preoccupied with acts of terrorism and the Free Aceh Movement (GAM) which disturbs political stability and the implementation of foreign policy. SBY is Indonesia's first president elected by a democratic mechanism through the election (Haryanto and Pasha, 2016: 243).

The domestic situation is also a decisive variable for foreign policy. The domestic situation of the Reformation era has not only changed SBY's view of Indonesian foreign policy, but SBY also made changes in foreign policy decision-making rather than during the New Order era which dominated by the military. According to Fathun (2017: 95) that the direction of SBY leadership is more "political economy" than "economical politic". Political economy is a pattern of government formed by SBY which is more dominant in relation to political efforts towards the economy. SBY also led institutional reforms that consolidated foreign policy-making in the Ministry of Foreign Affairs and the State Palace, thereby eliminating institutional competition over foreign policy between the military and the foreign ministry. SBY continued a process that begun under Hassan Wirajuda, whom he retained as foreign minister when he succeeded President Megawati Sukarnoputri, to shift responsibility for foreign policy from the military to the foreign ministry, and to professionalize the diplomatic corps. In doing so, the former general turned president made clear that, in a democratic Indonesia, the military would be subordinate to the foreign ministry on matters of diplomacy (Connelly, 2014: 3).

After the official appointment of Susilo Bambang Yudhoyono as the President of Republic of Indonesia, the cooperation between Indonesia and Russia was re-established, although it was not the first time that the normalization of relations between the two 


\section{Jurnal Ilmu Sosial Vol. 17 | No. 1 | Edisi Januari - Juni 2018 | Hall.1-20}

countries because the Post-Reformation relationship between Indonesia and Russia is good enough and there is cooperation during the Megawati administration era. Although the concentration of Indonesian foreign policy is more emphasize on the neighboring country. Since the New Order government, Indonesia's foreign policy embraced the theory of concentric circles (Concentric Circles Formula). The first Concentric Circle is ASEAN which is considered as the "cornerstone" of Indonesian foreign policy (Inayati, 2005: 35). The most important thing is the policy of foreign policy priority to the neighboring countries, but beyond that, SBY also try to cooperate with various countries including the United States, China, Japan, including Russia.

In relation to the prevailing international system, the SBY administration seems to be inclined to the opinion that the world is divided over the forces that are spread not only the US but also the EU, China, Russia, and Japan. In other words, SBY considers that the international order at the beginning of his reign is characterized by multipolarism. In multipolarism, interactions take place between different parties/actors, so the possibility of establishing a specific relationship such as during the Cold War with a commitment to the block to be followed is difficult. Interaction by one actor, with various countries leading to cross-cutting loyalties and alliances, will affect the level of hostility or friendship (amity and enmity) with one actor/other countries (Mingst 1999 in Hidayat, 2017: 233). Seeing the international situation like that, it seems SBY does not want to only work with one block only. The foreign policy and cooperation that SBY wants to build are with any block that can be beneficial to Indonesia's national interests.

In his annual press statement delivered on January 4, 2013, Marty Natalegawa set out Indonesia's foreign policy priorities. He outlined 9 specific objectives for 2013, which are (in summary): to improve bilateral cooperation with strategic partners; to expand Indonesia's non -traditional export markets; to intensify border diplomacy with Indonesia's neighbours; to enhance protection of Indonesians overseas; to maintain peace and stability in the region; to 'consolidate democracy and human rights values in the region and at the global level'; to strengthen regional economic resilience and growth; to contribute to global peace, security, and justice; and to promote a 'just global economic and development order' (Jakarta Post in Poole,2013: 1). Russia is seen as one of the strategic partners which is a priority for Indonesia's foreign policy. Moreover, Russia has advantages in the field of technology and military that can be used to improve and strengthen the ability of technology and military Indonesia.

Indonesia's contemporary foreign policy slogan is "a thousand friends-zero enemy" for the best of national interest, which was projected by the Ministry for Foreign Affairs in a 


\section{Jurnal Ilmu Sosial Vol. 17 | No. 1 | Edisi Januari - Juni 2018 | Hall.1-20}

statement released in January 2010. It clearly articulated that it would improve relations with every nation through bilateral ties and multilateral institutions. It also aspires to promote justice and order in the international arena, better investment policy for economic development, democracy, and consolidation in regional integration, protecting Indonesian nationals particularly migrant workers, maintaining national unity, and striving for a more effective foreign policy mechanism. This slogan and the strategy that goes with it is a Post1998 crisis evolution. The process to reach there is difficult. Any nation would face serious problems when the rule maintained for more than three decades were to be suddenly transferred (Puspitasari, 2010: 2). This slogan is very important to understand and become the principle for SBY government in seeing the world globally, making it a foundation for foreign policy. Although in the New Order era, the government at the time saw Russia as a threat, the SBY government tried not to feel worse in cooperation with Russia, plus the international situation at that time was not based on ideological interests as during the Cold War.

SBY's foreign policy statement was first disclosed in the forum before the implementation of Indonesia Council of World Affairs (IWCA), May 19, 2005. On that occasion, SBY stated that Indonesia's foreign policy is "navigating a turbulent ocean". The doctrine says that Indonesia combines its independence and active diplomacy by holding the principle not to regard anyone as an enemy and seek friends as much as possible (zero enemy and thousand friends). In view of SBY, the active freedom is defined as "independent of judgment" and "freedom of action" (Haryanto and Pasha, 2016: 245).

Yudhoyono's interpretation of the policy of free-and-active foreign policy differs from that of former Soekarno era, where the international political constellation at that time had only two major powers, so Hatta as the founding fathers said that in running an active free foreign policy, Indonesia should "sailing between two corals". The perception of the policy of foreign policy active by SBY as quoted from Yani (2010) is as follows:

First, Yudhoyono added the necessity of a constructive approach in the conduct of independent and active foreign policy. Indonesia ${ }^{\text {ee }}$ independence and activism must be combined with a constructive mindset. It denotes an ability to turn an adversary into a friend and to turn a friend into a partner. Constructivism helps Indonesia to use its independence and activism to be a peace-maker, confidence builder, problem solver, and bridge builder.

Second, independent and active means that Indonesia will not enter into military alliances. Indonesia has never engaged in a military pact with a foreign country, and Indonesia will continue its policy of not allowing any foreign military bases on Indonesian territory. 
and emerging powers, with the regions of the world, and with international institutions and a whole range of non-state actors.

Fourth, independent and active foreign policy should project Indonesia ${ }^{\text {ee }}$ international identity. Indonesia is the fourth most populous nation in the world, the worldes largest Muslim population, and the world ${ }^{\text {ee }}$ s third largest democracy. Indonesia is also a country where democracy, Islam, and modernity go hand-in-hand.

Fifth, independent and active foreign policy should reflect Indonesia ${ }^{\text {ee }}$ brand of nationalism that is open, confident, moderate, tolerant, and outward looking. This brand of nationalism must be at the root of Indonesiaes internationalism. This way, Indonesia"es independent and active policy becomes relevant both to Indonesiaes national interests and to the international community.

In dealing with other countries on a bilateral basis, SBY based the principles on the first and second points. In the first point, Indonesia is required to be "independent" meaning that Indonesia does not have to rely on a single force, such as the United States, Russia or China alone. However, Indonesia cooperates with all the blocks or countries. So is the second point in which Indonesia is not involved in a military alliance that could end up only emphasizing on a single block and fragmented to cooperate with other countries. This is what underlies Indonesia's foreign policy with Russia.

Yudhoyono's doctrine clearly adopts the "all-direction diplomacy". In practice, "all direction diplomacy" is implemented with Indonesia's participation in the frame of solidarity of developing countries and North-South relations. Indonesia's gait in the international world is increasing. Indonesia plays an active role in various international cooperation forums, and that participation makes Indonesia important to the world, both directly and indirectly. Another achievement, in this 21 st century, for the first time in the history of Indonesian independence, Indonesia has no enemy or state that is considered threatening this country, and no other countries perceive Indonesia as its enemy (Haryanto and Pasha, 2016: 248). Similarly, Russia's perception of Indonesia, because Indonesia no longer sees Russia as a threat as in the New Order era, Russia is also open in cooperation with Indonesia.

During the administration of SBY, SBY's foreign policy is inseparable from the need for domestic interest. Yudhoyono's policy laid the foundation of his foreign operations in three major national policies of foreign policy, contained in the Medium Term Development Plan (RPJM) of 2004-2009, namely: First, the stabilization of foreign policy and the optimization of Indonesian diplomacy in the conduct of foreign relations and implementation of foreign policy. Second, the enhancement of international cooperation aimed at optimally 
utilizing various opportunities in diplomacy and international cooperation, especially ASEAN cooperation besides countries with interests that are in line with Indonesia. Third, affirmation of world peace commitment made in order to build and develop the spirit of multilateralism in solving various international security problems (Haryanto and Pasha, 2016: 244). SBY's foreign policy platform is clearly stated in the RPJM which is the reference of the government's plan to operationalize foreign policy in the future.

The relationship between Jakarta and Moscow was also more intense when Indonesia was led by President Susilo Bambang Yudhoyono. Putin expressed his congratulations to SBY when SBY was elected president in 2004. Further, a meeting was held at the APEC summit in Santiago (Chile) and in Pusan, South Korea on November 19, 2005. Putin also sent a speech of grief related to the bombing and tsunami disaster hit Indonesia. This relationship continued when President SBY visited Russia on November 29, 2006 (Surya, 2009).

Beginning after SBY's appointment as President in October 2004, verbally Russian President Putin sent congratulations to Susilo Bambang Yudhoyono for his victory in the presidential election. Furthermore, on the day of the presidential inauguration on October 20, 2004, a phone conversation took place between Putin and SBY. This is a communication between the president of both countries which is very important in exploring cooperation between the two countries. In Coplin's (1992) view, general foreign policy consists of a series of decisions expressed through statements of a policy and direct actions.

Indonesia's foreign policy during SBY's time was based on a rationality rather than an emotional aspect of soft approach rather than hard power. In implementing its foreign policy, Indonesia does not base its attitude on excessive suspicion, fear or defensive, but the application of confidence and enthusiasm to establish partnerships with other countries in the struggle for national interests (Wirajuda, 2010: 343 in Darmawan, 2016). This is what makes Russia also open in welcoming the hospitality of Indonesia in bilateral cooperation. In the era of the administration of President Susilo Bambang Yudhoyono, Indonesia has the momentum to reestablish strategic cooperation with Russia. Indonesia's active foreign policy is not only concentrated on the United States, Europe, and China but also with Russia.

\section{Indonesia-Russia Cooperation}

During the reign of President Susilo Bambang Yudhoyono (2004-2014), it was a good time to resume strategic cooperation with Russia, which was formerly known as the Soviet Union. In the development of Indonesian foreign policy at the time, it was important to expand the strategic partners around the world. Russia is one of the countries with great potential, much cooperation between Indonesia and Russia in various fields. Among the most prominent potentials of many fields are the areas of cooperation in the economic, military, social and political fields. 
At a meeting between President Susilo Bambang Yudhoyono and Vladimir Putin on November 29, 2006, in Russia has agreed on a form of military, political and economic cooperation. In the field of economy, President Susilo Bambang Yudhoyono pushed Russian investment into Indonesia due to trading volume of both parties in 2005 with an estimated 680 million US dollars. That figure exceeds $42 \%$ of 2004 results (480 million US dollars). Elements of non-policy can encourage closer inter-State to strengthen trade relations. The non-policy elements that contribute to the proximity include geographic proximity (distance and common border), language similarity, legal system, and history (Jean in Putranti, 2017: 114). In this context, the historical relationship that makes Indonesia and Russia trust each other to conduct trade activities. In addition, Indonesia has the interest to open cooperation on nuclear energy as an effort to overcome the energy crisis that still continues to occur in the country. On the other hand, Russia has the interest to offset the dominance of US companies in Indonesia, especially the mining sector that has achieved huge profits. While in the military sector was agreed on the implementation of military cooperation 2006-2010.

Some forms of cooperation between the Government of Indonesia and Russia are realized by signing seven memoranda of understanding in the field of defense, politics, economy, and law. The seven noteworthy notes are the cooperation of space exploration for peaceful purposes, the cooperation of atomic energy use for peaceful purposes, cooperation between the judicial institutions, intellectual protection in technical military cooperation. In addition, a memorandum of understanding was also signed in the assistance of Russia-Indonesia military implementation (2006-2010), short visa exemption for official and diplomatic interests, and tourism cooperation. The signing of the agreement was witnessed by President Susilo Bambang Yudhoyono and President Vladimir Putin in the Malachite Fuyet room, the Russian Presidential Palace.

The form of respect and seriousness of both countries was also shown on 6 September, 2007, President Putin made an official visit to Indonesia. The visit was a counter-visit to President Susilo Bambang Yudhoyono's visit in December 2006 and was the first visit of the Russian President since 1991. During the visit, President Putin reviewed the cooperative relationships that have existed since 2003, particularly in the military and commercial economy.

Putin's visit, as well as SBY's visit to Moscow in December 2006, shows the potential for strategic cooperation between the two countries. It was proven that in the visit of SBY to Moscow, has successfully signed 10 agreements in various fields, ranging from security cooperation to the field of economy and tourism. Some circles in the foreign and defense departments informed that in Putin's visit to Jakarta in September 2007, the results were much larger or at least as large as SBY's visit to Moscow (Faradisah, 2012). 
1. The MoU of the Government of the Republic of Indonesia and the Russian government on cooperation in the field of limitation of negative impacts on the environment, signed by the State Minister for the Environment Rachmat Witoelar and Head of Rostechnadzor K.B Pulikopsky.

2. The MoU between the Ministry of Youth and Sports of the Republic of Indonesia and the Federal Agency on Physical, Cultural and Sports of the Russian Federation, on the cooperation of physical and sports training, was signed by the State Minister of Youth and Sports Adhyaksa Dault and Head of Rossport V.A. Fetisov.

3. Agreement between the government of the Republic of Indonesia and the Russian government in the promotion and protection of investments, signed by Chairman of BKPM M. Luthfi and Deputy Minister of Trade and Economic Development V.G Savalyev.

4. A cooperation agreement between the Indonesian Audit Agency (BPK) and The Accounts Chamber of the Russian Federation, signed by Anwar Nasution and Chairman of the Russian Audit Agency S.V. Stephasin.

5. MoU between the government of the Republic of Indonesia and the Russian government in cooperation against terrorism, signed by the Director General of America and Europe, the Ministry of Foreign Affairs of the Republic of Indonesia, Eddi Hariadhi, and the Deputy Minister of Foreign Affairs of the Russian Federation A. Losyukov.

6. Cooperation between the Government of the Republic of Indonesia and the Government of Russia in the extension of state debt to the Government of the Republic of Indonesia, signed by the Director General of Debt Management of the Ministry of Finance of the Republic of Indonesia Rahmat Waluyo and Deputy Minister of Finance of Russia A.A Storchak.

7. Cooperation program between the Ministry of Culture and Tourism of the Republic of Indonesia and the Federal Agency for Culture and Cinematography of the Russian Federation, signed by the Secretary General of Culture and Tourism Sapta Nirwandar and the Russian Ambassador to the Republic of Indonesia Alexander Ivanov.

8. Technical cooperation between the Ministry of Finance of the Republic of Indonesia and the State Cooperation Bank for the Development and the Foreign Economy (Vnesheconombank) in the field of technical procedures in the case of settlement and keeping accounts, signed by the Director General of Debt Management of the Ministry of Finance of Republic of Indonesia Rahmat Waluyanto and Deputy Finance Minister of Russia A.A. Storchak.

Seeing the memorandum of understanding signed over a lot (there are 8 points), I as a researcher will not explain one by one cooperation in various fields. Among the established cooperation, I will only describe the areas that are very prominent and large enough to see the results. Some areas of cooperation are as follows: 


\section{Military Cooperation}

The military is one of the most important areas for a country to defend itself against external threats. The country that has a strong military then he will have a high bargaining power in international relations, in addition to the economic field also affects a country to be strong. Military cooperation between Indonesia and Russia has long been established since the reign of Sukarno. Toward the early days of Indonesian independence, Indonesia gained much help from the Soviet Union in terms of military weaponry.

Indonesia-Russia strategic cooperation in the military is the most prominent among the others. This is because Russian technology and military are still a calculated force in the world. This military cooperation could be the "opening door" for the establishment of a strategic partnership in other fields. Geographically, Indonesia is vast country, encompassing thousands of islands from Sumatra to Papua, explaining that Indonesia needs a strong modern army to ensure national security.

The Soviet Union supplied a lot of military equipment to Indonesia, ranging from tanks, warships, and various types of fighter aircraft. In addition to supplying military equipment, the Soviet Union also provided technical training for Indonesian soldiers at military academies in Moscow, Saint Petersburg, Sevastopol, and Vladivostok. Russia also sent a thousand instructors to various regions in Indonesia, such as Jakarta, Surabaya, Bandung, and Madiun to train Indonesian troops. Russia is aware that as a new country, the Indonesian military has very limited experience, especially related to technical experience (id.rbth.com).

Some of the reasons Indonesia chose Russia as the newest military weapon producing country for the TNI are: First, the history of the Indonesian-Russian military relations. Second, ease of requirement of cooperation of military defense field from Russia. Third, Russia is more flexible about the price as it can be paid with the commodity owned by Indonesia. Fourth, Russia has military technology that is commensurate with Europe and the USA (www.politikindonesia.com). Russia has military power that can be favored so that Indonesia can adopt military system through the cooperation that has been done. In the field of military, cooperation with Russia, not only limited to cooperation alone but learn and absorb the science-technology from Russia. Russia is known to have a reputation as a fairly effective country in technology transfer. India and China have produced combat aircraft thanks to technical military cooperation with Russia. Indonesia also hopes that military defense cooperation with Russia can be like India and China. 
One of the cooperation in the field of the military is the procurement of armaments from Russia by Indonesia managed through the Department of Defense of the Republic of Indonesia. From year to year, the cooperation continues to increase, not limited to the procurement of squadrons Sukhoi fighter for the Air Force (TNI AU), but also for the Navy (TNI AL) and Ground Force (TNI AD). Like the procurement of 2 Kilo-class submarines, six Marine fighter vehicles, and four assault helicopters for the Army. The need for TNI's main weapons system equipment is made from the products of Eastern European countries. Especially for the batter, using Russian-made. The goal balances the military power of neighboring countries using US and European products. But it will not lead to an arms race that could threaten ASEAN's stability. This was conveyed by Defense Minister Juwono Sudarsono regarding procurement program of artificial Russian-made (news.detik.com).

To realize military cooperation, quoting from Faradisah (2012), Russia provides a US \$ 1 billion state credit for the procurement of Indonesian armaments for the period 20062010. This credit has the advantage of efficiency because it does not use management fee and other terms. The Ministry of Defense of the Republic of Indonesia uses a loan granted by Russia for the procurement of 10 MI-17-V5 helicopters and 5 MI-35P Helicopters along with their weaponry for the Army for the need for helicopters assault and transport; 2 Kiloclass submarines and 20 BMP-3F combat infantry vehicles for the Navy. After 4 Sukhoi is purchased, it will proceed with the procurement of 6 Sukhoi, consisting of 3 Sukhoi SU-27 units and 3 Sukhoi SU-30 units, as well as 6 packages of avionics equipment and weapons of Sukhoi TNI AU.

From year to year, the value of the military budget in Indonesia is increasing and the items are increasingly varied. "The procurement of the Sukhoi aircraft is to offset the F18 that will be owned by Australia, Singapore, and Malaysia. So there must be a minimum power of the equivalent tools of technology. We are not headed for an arms race." said Juwono at the State Palace, J1. Veteran, Jakarta, Wednesday, September 5, 2007 (news.detik.com).

Utilizing Russian loans to strengthen defense equipment in Indonesia benefits Indonesia in the midst of a funding crisis for reform and maintenance of defense equipment, purchasing weaponry through credit from Russia is needed to strengthen the Indonesian National Army in maintaining regional sovereignty. The addition of combat weaponry has an inhibiting effect on other countries that try to disturb Indonesia's territorial sovereignty.

Procurement of armaments from Russia is a rational choice when domestic strategic industries have not been able to meet the needs of military equipment and technological 
equipment. Using the US or European products, in addition to the more expensive price, there are always political obstacles that can complicate Indonesia in the future. Russia, in general, is not difficult about licenses, permits, and political requirements. The purchase of armaments from the United States and the European Union is generally complicated by the requirements of human rights enforcement (linked to Aceh, Poso or Papua), licensing issues, and complicated purchasing procedures. Experience with the UK, for example, the Scorpion tank and the Stromer assault rifle for operations against the Free Aceh Movement (GAM) should not be used in Aceh because of the terms of cooperation only for outside defense (www.antara.co.id).

The cooperation of purchasing military equipment from Russia is considered the most profitable. In addition to the uncomplicated process, direct purchases of government-appointed bodies can save a 40 percent budget, because without going through brokers. Payment system proposed by the government of Indonesia one of them with the system of buying armaments purchase. Buying armaments with coal commodities, for example, provides an opportunity for the Russian government and entrepreneurs to invest in coal exploration in Indonesia, not to exchange coal commodities with armaments (www.antara.co.id).

In the long run, the procurement of armaments policy thus establishes a balance of relations between the major countries that become strategic partners of the Republic of Indonesia. Procurement of US-made, EU, Chinese or Australian military equipment will continue according to the needs of each generation. But referring to the bitter experience of arms embargoes from the US and its allies, by itself RI 'adjust' themselves. "For example the procurement of transport aircraft, it is from the US because it is not sensitive (in weapons systems), but if the tools (more sensitive), from Eastern Europe," according to the Minister of Defense (news.detik.com).

After the lifting of the US military embargo on Indonesia, the TNI is now very selective in cooperation. There is a requirement to offer weapons procurement to Indonesia, i.e. no political or embargo conditions. Indonesia embraces a new system in the provision of military weaponry. The most important system of arms purchases is done directly by the Indonesian government without going through intermediaries.

Quoting Faradisah (2012), cooperation with Russia is one way of Indonesia to reduce Indonesia's dependence on the United States in the field of weaponry which at that time has reached 70 percent. As a result of the US military embargo against Indonesia nearly fourteen years, resulting in the condition of TNI weaponry made by the United States is very bad, because of the absence of maintenance and maintenance of spare parts from the United States. 


\section{Jurnal Ilmu Sosial Vol. 17 | No. 1 | Edisi Januari - Juni 2018 | Hall1-20}

Some US-made armaments used by the TNI ended in an accident that killed TNI soldiers who deservedly died for defending Indonesian homeland, not killed by a system that has expired.

The cooperation of the Indonesian government and the Russian government in the procurement of military equipment became a model of further military cooperation for both countries. Procurement of armaments in Indonesia will be done in stages. Observations conducted by the army, submission conducted by Mabes TNI, and the decision taken by the Ministry of Defense. Russia and Indonesia need each other with the same goal of world peace, security, and prosperity. International military agreement in 2004-2009 as quoted in the official website of the Department of Foreign Affairs of Indonesia (www.deplu.go.id), among others:

1. Minutes of Meeting Between the Republic of Indonesia and the Russian Federation to Promote Bilateral Cooperation in Defense and Security. (Note between the Meetings between the Republic of Indonesia and the Russian Federation on the Improvement of Bilateral Cooperation in the Field of Defense and Security) Jakarta, 17 September 2004.

2. Memorandum of Understanding Between the Government of the Republic of Indonesia and the Government of the Russian Federation on Assistance in Implementation of the Program of the Indonesia-Russian Military-Techincal Cooperation for 2006-2010. (Memorandum of Understanding between the Government of the Republic of Indonesia and the Government of the Russian Federation Regarding Assistance in the Framework of Implementation of Indonesia-Russia Military-Technical Cooperation Program 20062010). Moscow, December 1, 2006.

3. Agreement and Obtained in the Course of Bilateral Military-Technical Cooperation. (Agreement Between the Government of the Republic of Indonesia and the Government of the Russian Federation Regarding the Protection of Reciprocity of Intellectual Activity Results Implemented and Acquired in the Framework of Military-Military Bilateral Cooperation.) Moscow, December 1, 2006.

This cooperation is also a counterweight to Indonesia's power in Southeast Asia. As it is well known that the military capabilities of Singapore, Malaysia are some degree higher than Indonesian military capability, some cases can be references for example Ambalat case, where Indonesian combat equipment is far behind compared to neighboring countries whereas Malaysia's armaments are far below Indonesia. The creation of regional stability in Southeast Asia will be able to raise Indonesia's bargaining position in Southeast Asian politics map so that multipolarism in Southeast Asia will be created, which until now the dominant country of Southeast Asia is Singapore (Surya, 2009). Military cooperation 
cooperation of military alliances, but cooperation in one area is needed to maintain the sovereignty of the state of Indonesia and anticipate the threat of Indonesia from outside countries. It can be said that this cooperation in the military field is in line with Indonesia's national interests.

\section{Social Cooperation}

Cooperation in the social field has various perspectives. One form of social cooperation is in the case of natural disaster management. This form of cooperation, unlike the other cooperation, cannot be valued profitably. But in this cooperation, the main foundation is a sense of humanity and friendship between the two countries. One of the most dangerous threats to the 21 st century is Natural Disasters such as earthquakes, tsunamis, wildfires, floods and so on. As a result, hundreds of thousands of lives were killed in a pathetic manner. Millions of people lost their homes and possessions. State financial losses reach billions of US dollars.

In that context, governments around the world, including Indonesia, have sophisticated strategies and equipment, to take early prevention and to anticipate disasters. In the Tsunami that hit Aceh in 2005, more than 300 thousands people died. An event on such scale that is not much different also occur on the island of Nias. Forest fires also hit Kalimantan and North Sumatra, thus drawing criticism from Malaysia and Singapore. A series of natural disasters that happened to make SBY needs help and support in solving the disaster problem.

Learning and absorbing technology from other countries including one from Russia, of course, is a strategic option to be applied by Indonesia. In this regard, Russia is known to have a reputation as a country that is quite effective in building disaster management systems. In assisting Indonesia in tackling the post-disaster situation, Russia contributed to the Amphibi Be-200 (Multipurpose Amphibious Jet) aircraft aid in forest fires in Kalimantan in 2006. It turns out that Russia has not only succeeded in helping post-disaster forest fires, in fact hundreds of thousands of Indonesians was saved (www.nu.or.id).

Quoted Hendrajit (2007) as written by a Foreign Ministry staff member said that if a natural disaster phenomenon that occurred in Indonesia will be an important consideration for the offer of Russian assistance in the field of technology to Indonesia. One consideration is that by learning from the experience of Russia assisting Indonesia in forest fires in Kalimantan and North Sumatra in 2005, the State Ministry of Research and Technology holds that if Indonesia has Multipurpose Amphibious Jet like Be-200, the number of casualties due to forest fires as well other natural disasters that require immediate evacuation of victims, can be reduced to a minimum. If anticipated as soon as possible, it also avoids strong criticism from neighboring countries such as Malaysia and Singapore. 


\section{Economic Cooperation}

Another strategic aspect that became an important discussion in Putin's visit to Jakarta was in the economic field, especially the energy sub-sector. Indonesia is a gas exporter country and is still listed as one of the largest gas exporters in the Asia Pacific. So it is important for Russia to establish coordination with Indonesia in this field. IndonesiaRussia cooperation in the energy sub-sector, in its development, can be an "entrance" for Indonesia-Russia strategic cooperation in Southeast Asia. Because in Central Asia, America and Russia have actually been fought and compete in the seizure of oil resources in the region since the late 1990s. Consider a study conducted by former President Jimmy Carter Zbigniew Brzezinski's advisor to the sponsorship of the Council of Foreign Relations (CFR) in 1997.

The Brzezinski study explicitly mentions Russia and China as a threat to American interests in the Central Asian border region. So the CFR study recommended policy designers and strategies in Washington to manage and manipulate some small countries in the region such as Ukraine, Azerbaijan, Kazakhstan, and Iran, as a pro-American counterforce to stem the influence and movement of Russia and China in mastering oil, gas, and mineral resources in Central Asia. With these facts, a similar situation could happen in Southeast Asia. In a sense that America also views the Chinese and Russian maneuvers in Southeast Asia as a threat and a hindrance in America's efforts to control access to oil, gas, and minerals in Southeast Asia, particularly ASEAN. This is the strategic side of IndonesiaRussia cooperation in the energy sub-sector. Cooperation and coordination between Russia and Indonesia are not only limited in the field of gas but also in the field of oil and minerals, in its development into the partnership and friendship between the two countries in all areas.

In addition, in October 2009, Indonesia - Russia Joint Business Council was formed. The body was formed to promote economic cooperation between the two countries. Through this forum, Indonesian companies will cooperate with companies from Russia in the field of oil and mining, Pertamina with LukOil (petroleum), PT. Antam with RusAl (Bauxite), and PT. Minang Jordanindo with Chelyabinsk Tractor Plant (Tractor). The forum also discussed the cooperation of railway and coal terminal development in Central Kalimantan is also being explored with Russia (Surya 2009).

The signing of the cooperation as quoted from Surya (2009) was conducted by the chairman of KADIN (Indonesian Chamber of Commerce) and RFCCI (Russia Federation Chamber of Commerce and Industry). This cooperation is to respond the Indonesia-Russia trade figures which increased significantly in 2008 to reach US \$ 1.667 billion or an increase 
of $114.49 \%$ compared with the value of trade in 2007 . The number of Russian tourists who came to Indonesia also experienced a significant increase. In 2008, the number of Russian tourists reached 69,625 people or an increase of 54.5\% compared with the figure in 2007 (45,064 people). Russian tourists are known as tourists with long stays and high expenses. This is expected to increase Indonesia's revenue from the tourism sector which is currently one of the mainstay sectors of the Indonesian government.

A cooperation in the field of economics is a cooperation that usuallu done by a country, especially Indonesia with Russia to be able to take advantage and used for the prosperity of the people. In this cooperation, the indicator can be seen clearly from the percentage or the number of figures between expenditure and income in a country. Unlike the cooperation of other fields, especially the social field which is not quite easy to see the indicator.

\section{Political Cooperation}

From all the possibilities of cooperation mentioned above, cooperation in the political field is also an important aspect. Despite the close relations between the two countries, the interests of Indonesia and Russia in international forums are in line. The two countries' main opinion on the main international issues such as counterterrorism, separatism, and extremism, also share the same perception. The events of the World Trade Center (WTC) bombing in the United States on September $11^{\text {th }} 2001$ had an impact on the change in the foreign policy orientation of countries in the world in their domestic policies. This can be seen from the reaction of almost all countries in the world who are also in the position of "fighting terrorism", as well as Indonesia and Russia (Windiani: 137). This common perception is the fundamental asset of cooperation in the political aspect.

The attempts to normalize the situation in North Korea, Afghanistan, Iraq, IsraelPalestine, between Indonesia and Russia is roughly the same. Through the momentum of Putin's visit to Jakarta, Indonesia and Russia increasingly improved their bilateral cooperation in politics in better and productive way. Moreover, the cooperation between Indonesia-Russia politics in multilateral also increasingly improved. As in the forum of the United Nations (UN) where the cooperation between Indonesia as a non-permanent member of the Security Council and Russia as a permanent member remain solid and compact because both are important power. So in the case of UN reform, for example, America and the countries of Western Europe cannot simply underestimate Indonesia and Russia, which of course also tend to be in line with the People's Republic of China.

Indonesia also politically supports Russia's membership in the WTO where support from WTO member countries is needed by Russia who at that time wants to join the WTO. 
Quoting Surya (2009), good relations between the two sides of the international world are seen from the mutual support for each of their candidacies to fill certain positions in international bodies. The example is at the 24th IMO General Assembly Meeting in London, Indonesia has been re-elected as council member of Council IMO category C for the period of 2005-2007, this is one of the support of the Russian side. Russia supports Indonesia's candidacy and position in international institutions such as the UN Human Rights Commission, ILO, ITU, CoE, and ECOSOC, and supports Indonesia in nominating DKPBB as a non-permanent member of the period of 2007-2008. This mutual support contributes positively to the two countries in the international world because both countries are looking for bargaining position in the international world.

This cooperation in politics not only implies mutual support in international forums. The implications of such support may have an impact behind the political cooperation that affects cooperation in other areas particularly the military and the economy.

\section{CONCLUSION}

The description of bilateral relations between Indonesia and Russia cannot be separated from the national interests of each country to establish relations and cooperation. Indonesia's foreign policy principle is not dependent on only the geopolitically close country but also the geographically far-off country, given certain objectives for peace-building by taking into account military, political, economic and social cooperation, resulting in a more harmonious relationship between the two countries. It can be said that the relationship cannot be separated from the existence of interrelated relations that contain reciprocity or a reciprocal relationship between the two countries.

The cooperation between Indonesia and Russia cannot be separated from the SBY doctrine of "million friends, zero enemy" who always see the potential and opportunities that are very profitable for the national interests of Indonesia. Although the concentration of Indonesia during the SBY period is more emphasized on cooperation with the neighboring countries (Southeast Asia and Asia Pacific) but because there is a great potential in Russia, Indonesia is interested to establish a cooperation. This made the foreign policy between Indonesia and Russia significantly increased after the Reformation era, which no longer saw Russia as a threat as in the New Order era. Cooperation between Indonesia and Russia is implemented in various fields. This study, however, found four prominent areas, i.e. the cooperation in the military, social, economic, and political. 
The high tech capabilities of Russia's most sophisticated military technology make the most prominent cooperation in military cooperation, in which Indonesia's national interest is to offset the military power of the sophisticated military weapons in neighboring countries (Singapore, Malaysia, and Australia). Barriers to military cooperation with the United States such as embargoes and complicated political requirements led Indonesia to meet its military needs from Russia.

\section{BIBLIOGRAPHY}

Connelly, Aaron L., October 2014. Indonesian Foreign Policy Under President Jokowi, Lowy Institute for International Policy

Dermawan, Windy, 2016, Maritime Diplomacy Sebagai Strategi Pembangunan Keamanan Maritim Indonesia, Wacana Politik, Vol. 1, No. 2, Oktober: 166-174

Fathun, Muhamad Laode, 2017, Mobilisasi Wisatawan Asing Terhadap Potensi Ancaman Non-Tradisional di Indonesia, Jurnal Ilmu Sosial, Vol. 16, No. 2, Juli-Desember: 94112

Inayati, Ratna Shofi, 2005, Pemerintahan Susilo Bambang Yudhoyono dan Politik Luar Negeri Indonesia, Jurnal Penelitian Politik, Vol. 2, No. 1: 35-49

H, Bambang, 2005," Indonesia Mempererat Hubungan Militer Dengan Rusia” [online]. Dalam http://www.politikindonesia.com/index.php?k=politik\&i=1805-IndonesiaMempererat-Hubungan-Militer-Dengan-Rusia [diakses 3 Agustus 2015]

Harini, Setyasih, 2012, Kebijakan Presiden Vladimir Putin dalam Menjalin Kerjasama Dengan Indonesia, Jurnal Transformasi, Vol. 14, No. 22: 1-8

Haryanto, Agus dan Iman Pasha, 2016. Diplomasi Indonesia, Realitas dan Prospek. Yogyakarta Pustaka Ilmu

Hendrajit, 2007, “Makna Strategis Kunjungan Presiden Putin Ke Indonesia” [online]. Dalam http://www.nu.or.id/post/read/9722/makna-strategis-kunjungan-presiden-putin-keindonesia [diakses 30 September 2015]

Hertanto, Luhur, 2007, "Persenjataan Rusia untuk Jaga Keseimbangan” [online]. Dalam https://news.detik.com/berita/826161/persenjataan-rusia-untuk-jaga-keseimbangan [diakses 5 Agustus 2015]

Hidayat, Nizar Muhammad, 2017, Analisis Kebijakan Pemulihan Citra Indonesia Pada Masa Kepemimpinan Presiden SBY, Jurnal Administrative Reform, Vol. 5, No. 4, Desember: $227-242$ 
Novana, Rindu Faradisah, 2012, Kerjasama Indonesia Dengan Rusia Dalam Bidang Pertahanan Militer Pada Masa Pemerintahan Susilo Bambang Yudhoyono Periode 2004-2009, Jurnal Transnasional, Vol. 3, No. 2, Februari: 1-18

Poole, Avery, 2013. A "democratic" process? Change and continuity in foreign policymaking in Indonesia: School of Social and Political Sciences, The University of Melbourne Prepared for Australian Political Studies Association (APSA) Annual Conference Draft September 2013

Puspitasari,Irfa, August 2010, Indonesia's New Foreign Policy-'Thousand friends-zero enemy', Institut for Defense Studies and Analysis (IDSA) Issue Brief

Rasyid, Fauzan Al, 2015, "Kisah Persahabatan Jakarta dan Moskow: 65 Tahun Pasang-Surut Relasi Dua Negara" [online]. Dalam https://id.rbth.com/politics/2015/02/24/ kisah_persahabatan_jakarta_dan_moskow_65_tahun_pasang-surut_relasi_d_26899 [ diakses 16 Agustus 2015]

Roy, S.L. 1991. Diplomasi, diterjemahkan oleh Herwanto dan Mirsawati. Jakarta: CV. Rajawali

RI-Rusia Jajaki Kerjasama Teknologi Pertahanan, 2007 [online]. Dalam https:// www.antaranews.com/berita/76303/ri-rusia-jajaki-kerjasama-teknologi-pertahanan [diakses 3Agustus 2015]

Coplin, William D., 1992. Pengantar Politik Internasional: Suatu Telaah Teoretis, terj. Marsedes Marbun, Edisi Kedua, Bandung: Sinar Baru.

Putranti, Ika Riswanti, 2017, Multilingualism And ASEAN Single Market: In The Perspective of International Trade Facilitations, Vol. 16, No. 2, Juli-Desember: 113135

Surya, Aelina, 2009. Antara Indonesia dan Rusia, Sebuah Tinjauan Sejarah. Bandung: Universitas Pajajaran

Windiani, Reni, 2017, Peran Indonesia Dalam Memerangi Terorisme, Jurnal Ilmu Sosial, Vol. 16, No. 2, Juli-Desember: 136-153

Yani, Mochamad Yanyan, 2009, Change And Continuity In Indonesian Foreign Policy, Sosiohumaniora, Vol. 11, No. 1, Maret : 1 - 16 